\title{
A More Just, Inclusive Future for Sports
}

\section{Dionne Koller, Guest Editor}

This issue of the Journal of Legal Aspects of Sport (JLAS) was dedicated to women in sports law, with a specific emphasis on inclusiveness and new ideas. For decades, the central focus of the law and policy directed to women and sports was Title IX enforcement and securing opportunities for participation. As we approach Title IX's 50th anniversary, it is clear that the law has greatly expanded participation opportunities for women and powerfully altered the norms around women and sports. Nevertheless, much work remains. ${ }^{1}$ Women and girls still do not enjoy the full measure of equality that Title IX guarantees, and women's sport at all levels still does not get the attention, resources, and respect that it should. ${ }^{2}$ The COVID-19 pandemic has only exacerbated this issue.

Yet beyond opportunities for participation, perhaps the greatest legacy of Title IX is that it has dramatically expanded the scope of law and policy issues women now claim in the realm of sport. While important, women and girls no longer simply seek assimilation into a model for sport created by and for men. They seek to inhabit sport as an area in which they can compete, coach, lead, and shape their experiences as full participants. They strive to lay claim to sport as equal partners in the enterprise, not guests to be invited in or accommodated. It is this next wave of women in sport who undoubtedly will continue working to break down barriers around equal pay, equal treatment, and equal access. And in this wave, women will go beyond the limits of formal equality. Women — all women — will play a key role in updating the social construct that we call sports to be more inclusive, with an expanded purpose and greater concern for the rights of athletes.

This special issue of $J L A S$ aims to explore the many different facets of the issue of women in sport today. We welcomed articles that look forward,

\footnotetext{
Women's Sports Foundation, Chasing Equity: The Triumphs, Challenges, and Opportunities in Sports for Girls and Women, 18 (2020).

2 See, e.g., Alan Blinder, Report: N.C.A.A. Prioritized Men's Basketball 'Over Everything Else', The New York Times (Aug. 3, 2021), https://www.nytimes.com/2021/08/03/sports/ncaabasketball/ ncaa-gender-equity-investigation.html
}

Dionne Koller, JD, is a professor of law and director of the Center for Sport and the Law at the University of Baltimore School of Law. Her research interests include Olympic and amateur sports law. Email: dkoller@ubalt.edu 
interrogating settled ideas about the purpose and conduct of sport, and who is eligible to participate. We also included articles that look back, taking stock of where we have been and how that informs current applications of the law. In short, like the many different women who participate in sports and the many different ways that they do, this issue sought to create an elevated, diverse discourse on the issue of women in sport.

Importantly, these articles provide an analysis of legal issues affecting women in sport against the backdrop of unprecedented athlete activism and athlete success in courts ${ }^{3}$ and legislatures. ${ }^{4}$ For instance, the movement to allow college athletes to reclaim their name, image, and likeness (NIL) rights will undoubtedly benefit women and their sports. ${ }^{5}$ But more than the financial benefits, reforms such as those focusing on athlete NIL demonstrate that unquestioned, total deference to sport regulators is unnecessary and unwarranted.

Arguments for reform often prompt concern from sport administrators that change will diminish or destroy the "magic" that is sport. ${ }^{6}$ Indeed, in nearly every context where athletes and their supporters have advanced arguments for fundamental fairness, equality, and the protection of athlete health and wellbeing, sport regulators have countered with dire predictions that the entire model for sport will be threatened. The arguments always center on vague predictions of harm and shifting definitions of terms like "amateurism" and "competitive balance." Across all levels of sport, the arguments are the same and the predicted harm never materializes. The NCAA warned that Title IX would destroy, among other things, football. Major League Baseball argued that eliminating the reserve clause to permit free agency would irreparably harm the game. Olympic officials asserted that allowing professionals into the Games would kill the Olympic model within a few years. The PGA Tour argued that Casey Martin's claim to protection under the Americans with Disabilities Act would deal a mortal blow to golf, if not all sports. None of these predicted harms have come to pass. Instead, what is clear is that reforms that serve to promote athletes' rights and a more inclusive model for sport have strengthened the integrity, sustainability, and popularity of the games we love. Read the articles in this volume with that in mind.

\footnotetext{
3 National Collegiate Athletic Ass'n v. Alston, 141 S. Ct. 2141 (2021).

4 See, e.g., S.B. 206, 2019-2020 Reg. Sess. (Cal. 2019) (codified at CAL. EDUC. CODE § 67456), https://leginfo.legislature.ca.gov/faces/billTextClient.xhtml?bill id=201920200SB206; Empowering Olympic, Paralympic, and Amateur Athletes Act of 2020, P.L. No. 116-189 (10/30/2020); College Athletes Bill of Rights, S. 5062, 116th Cong. (2020) https://www.booker.senate.gov/imo/ media/doc/College $\% 20$ Athlete $\% 27 \mathrm{~s} \% 20$ Bill.pdf.
}

$5 @$ @ByBerkowitz, Twitter (July 8, 2021) (“Over 40 U.S. Olympians are especially well-positioned to leverage NCAA's new NIL setup, led by women's gymnasts who, according to NCAA, now can keep money from post-Oly exhibition tour").

${ }^{6}$ See, e.g., NCAA v. Alston, Case No. 20-512, Brief for Petitioner (U.S. Feb. 1, 2021). 
In that spirit, the articles featured here provide important, timely legal and policy analysis from a diverse group of voices to move the sports law conversation ever forward. However, high-quality, creative legal analysis relies on individuals who become high-quality, creative lawyers. To that end, I asked a talented group of women sports lawyers and academicians to provide advice for those who are interested in getting into the field. Their insights follow.

\section{Say "Yes" Twice}

\section{Jodi Balsam ${ }^{7}$}

Gaining a foothold in sports law is as much about what you do outside the workplace as how you spend your billable hours. Be bold and insert yourself into the community of sports lawyers - through bar and professional organizations, conference attendance, dedicated CLE programs, and published writings. And then say "yes" twice-yes to showing up at these opportunities and yes to taking on support and leadership roles. I was a junior lawyer at a big law firm with a crushing workload when I said "yes" and volunteered for my local bar association's Sports Law Committee. Then I said "yes" again and volunteered to help research and cite-check a Committee white paper on an important legal issue affecting the industry. My reputation as a reliable and solid contributor was sealed among the senior ranks of the sports law community, and led to an in-house job at a sports league.

As this is a special women's issue, I should say something about the relevance of gender to the work of sports lawyers. When I practiced law-both at the firm and the sports league - the environment was far more male dominated than it is now. But even then, the meritocracy that defines athletic competition translated to the office. I never felt limited by my gender, but only propelled by my hard work and strong performance. Today, women have more opportunity in sports law than ever before, especially with the increasing number of women sports fans and the explosion of female amateur and professional sports. Be creative and entrepreneurial about gaining a foothold in the industry. Above all, sport is fundamentally about people-get to know them in all ranks of the game and let them get to know you, especially your passion for sport and your ability to help them reach their goals.

\footnotetext{
7 Jodi Balsam is an associate professor of clinical law and director of externship programs, Brooklyn Law School. Balsam previously served as Counsel for Operations and Litigation and was Of Counsel, Football Operations for the National Football League.
} 


\section{Prepare for Your First Opportunity}

\section{Tan Boston ${ }^{8}$}

For as long as I can remember, I have been athletic and enamored with all things sport. The legal aspects of sport became a passion for me after I spent a summer interning at a large Miami law firm. Upon returning to law school and reflecting on my summer experience, I realized that if I was going to spend most of my waking hours working, then the work would have to be something that I truly enjoyed. From then on, I actively sought out experiences where I could combine my love of sports with the law.

If you are considering a career in sports law, the first thing that you should know is that entering this field is not easy, and that doing so as a woman adds to the challenge in some very predictable ways. At least initially, you should be prepared to hear "no" more often than you hear "yes." The key is to keep knocking on doors literally and figuratively until you get to "yes." A few ways to improve your odds of getting to "yes" include joining sports law organizations, attending conferences, and networking with sports professionals that are already in close proximity to you.

I am not at all embarrassed to say that multiple sport organizations declined my offers of assistance when I was a law student. The first "yes" that I received was from the University of Virginia's then athletic director, who offered me an opportunity to serve as a teaching assistant for a college athletics course. At the time, the experience seemed insignificant but it served as the foundation for the rest of my sports law journey by opening the door for me to work at the NCAA (which had been a dream of mine) and by preparing me for a career in academia.

Thus, my best advice to those interested in pursuing a career in sports law is to ensure that you are well-prepared for your first opportunity. If you have yet to receive an opportunity to work in this exciting field, you can start preparing now by learning as much as possible about substantive areas of law relevant to sports (e.g., contracts). Such preparation is critically important, as your financial circumstances may require that you seek other employment while you pursue your dream career in sports law. Best wishes for an enjoyable journey, wherever your dreams may lead you!

\footnotetext{
8 Tan Boston is a visiting assistant professor of law at the University of Dayton. She also serves on the Executive Board for the Sports Law Section of the Association of American Law Schools.
} 


\section{Be Flexible}

\section{Lindsay Brandon ${ }^{9}$}

First and foremost, if you want to get into the field of "sports law," broaden your understanding of what that means. There are plenty of people that say they want to go into the field, but they usually mean "I want to be general counsel for a team" or "I want to be a sports agent." But sports law encapsulates so much more than that, including (but not limited to): branding, real estate, the Olympic movement, anti-doping, and safeguarding.

I did not know that I wanted to practice in the field of sports until I had already been out of law school for a couple of years, so I went back to school to get my LL.M. in International Sports Law. While I certainly do not think that this is a prerequisite, my law school did not have a sports law program while I was enrolled. During my LL.M. program, I was introduced to the diverse set of practices that exist under the sports law umbrella, including my current practice as an attorney for athletes mainly in administrative disciplinary matters.

Frankly, the more flexible you are willing to be, the better your chances of getting into the sports practice. This includes being willing to work internationally; there are governing bodies and sporting federations across the world who are looking for legal assistance (and often interns, if you happen to be looking for immediate opportunities). Even if it might be something you do not think you are interested in, you might find yourself surprised to find out otherwise.

If, however, you are already a practicing attorney, reflect on your skillset and figure out how that might parlay into the field of practice you want to join. For example, lots of professional teams and leagues prefer candidates with transactional experience.

If you find yourself striking out, look at working with a sporting brand (or even a company that is a frequent sponsor of sports teams and/or organizations) that can be a valuable steppingstone for your legal practice.

Finally, take advantage of organizations like Women in Sports Law and the Sports Lawyers Association. Although in-person events have been paused due to the pandemic, there are still online opportunities to network. Do not be afraid to reach out to their respective members if you have questions about a certain type of practice.

\footnotetext{
9 Lindsay Brandon is an associate at the Law Offices of Howard L. Jacobs. Her practice focuses primarily on representation of athletes in arbitration of anti-doping and SafeSport matters, as well as in team selection disputes.
} 


\section{Work Ethic (and Golf) Will Serve You Well}

\section{Sophie Gage $^{10}$}

Though there's not a singular path to a successful career in sports, there are a few key skills which I have found in common among those I greatly admire. The most obvious is a relentless work ethic. You don't have to be the most talented player on the field (or the smartest person in the room), but if you truly put in the effort to master your craft, you'll distinguish yourself from the rest of your peers. Focus less on being the last person to leave the office and more on ways to improve quality, efficiency, and productivity. Take your work ethic a step further by establishing a meticulous attention to detail. The impact of this habit on your work product and reputation will surprise you. Nurture your intellectual curiosity and strive to be well read. You'll find this will enable you to navigate everyday conversations and networking with ease.

Some of the best advice I received as a young girl was simply, "Learn to play golf and you'll have a skill and hobby for life." You don't need to shoot for a spot on the LPGA tour or have a single digit handicap, but a basic understanding of the game and a willingness to hit the links with your colleagues and business associates can create truly unique opportunities for relationship building and camaraderie. Even when you have a bad round, the time spent outdoors will be a welcomed and refreshing mental retreat.

\section{Think Outside the Box}

\section{Tammi Gaw ${ }^{11}$}

There has never been a better time for women to get into sports law. This is not just because the landscape of sports is getting more diverse, but because technology and the growth of sports make the industry easier to navigate. Whether you are just out of school, or looking to make a career change, keep the following suggestions in mind:

\footnotetext{
10 Sopie Gage is Senior Business Counsel, Business and Legal Affairs, for the NFL Players Association.

11 Tammi Gaw is the founder of Advantage Rule, LLC.
} 
Get a mentor. There are many women working in sports willing to be mentors and guides. Some of them may be executives, and not lawyers, but can provide valuable connections and suggestions of how to break into the field of sports.

Join organizations and networking groups. Professional groups are some of the best ways to learn about aspects of sports law, and to network with colleagues. Organizations that host conferences or webinars can expose new sports lawyers to aspects of sports law with which they might not be familiar.

Think outside the box. Many lawyers think that the best opportunities in sports are with the biggest leagues or working as an agent. The real opportunities for substantive work are often found with smaller or newer leagues, and that experience looks great to future employers. In the U.S., breakout leagues for rugby, lacrosse, and e-sports can provide lawyers with substantive experience and autonomy that getting lost in the shuffle at a larger league or organization can't always provide. If working internationally is your goal, take the initiative to attend conferences in other countries. Bonus points if you become conversational in multiple languages!

Create your own content. Use social media and networking platforms to your advantage. It costs very little money to host a site where you can create content (audio/video/written) and circulate it on platforms like YouTube, Twitter, and LinkedIn. Be aware that your social media presence can influence your future employment, so be judicious about what you post and share.

Understand that "sports law" is a misnomer. What we commonly refer to as "sports law" is actually various areas of law that happen to also apply to sports. Lawyers that want to work in sports should become knowledgeable in practice areas like labor and employment, antitrust, real estate, sponsorships, or immigration law.

Intern or volunteer, if possible. Internships can be valuable, but not all lawyers can afford to include them in their career plans. Be on the lookout for volunteer opportunities that offer a chance to network with colleagues and learn new skills.

Be unique. Don't be afraid to be yourself. Women lawyers often feel that they have to blend in and not stand out. Some of the most successful women in sports have successfully used their individual personalities to leverage future career opportunities. 


\section{Be Persistent}

\section{Andrea Kimball ${ }^{12}$}

My advice to those considering a career in sports law is to never give up. It was always my dream to work in sports after law school, but inertia and the perks a big law firm offered delayed that dream by 20 years. A few detours along the way does not mean you cannot be successful as a team's general counsel or a league attorney.

Many law students also think that teams only hire transactional lawyers to serve as in-house counsel. That is not true. I considered myself a "litigation generalist." During my 19 years in private practice, I litigated cases involving intellectual property, contracts, and product liability, as well as business and entertainment disputes. Rather than focusing on one specific area of the law, I advised clients on issues ranging from employment law and insurance, to contracts and licensing, and I developed a "toolkit" of knowledge on many legal subjects. This allowed me to confidently step into the role of general counsel when the opportunity arose. Over my last five seasons as in-house counsel, I have used these experiences to offer creative solutions to problems and effectively manage risk.

I encourage everyone who dreams of working in sports to keep pursuing that dream. There are many paths to a rewarding career in sports law. You can start as a junior lawyer working for a university, team, or league; or you can build your toolkit in the private sector before making the leap as a seasoned lawyer. In choosing to pursue the latter, you are able to offer experience and knowledge that you would not have gained if you had only worked in sports law after school. The most important thing to remember is that it is never too late to achieve your dream of becoming a sports lawyer.

\section{Be Positive, Be Prepared}

\section{Lisa P. Masteralexis ${ }^{13}$}

Much has changed since I entered the field. While there are new niches and opportunities, there is greater competition. Find your passion and hone in on setting yourself apart in that niche.

\footnotetext{
12 Andrea Kimball is the Vice President and General Counsel of Sporting Kansas City. Kimball oversees all legal matters for the Major League Soccer franchise.

13 Lisa P. Masteralexis is the Senior Associate Dean in the Isenberg School of Management and a professor in the Mark H. McCormack Department of Sport Management at the University of Massachusetts at Amherst.
} 
Build a network of relationships. People may advise you to build and guard your network, controlling it for yourself in this hyper-competitive field. I approach networking differently. I'm a connector and get joy from helping others. When I find relationships that will be mutually beneficial, I have an urge to help others connect. I never come into a networking relationship to get something out of it. I come into it seeking a connection. Once a relationship is built, unexpected opportunities present themselves.

You may be the only woman in the room. Be aware you are, but do not fixate on being the only woman. Shift your thinking. Focus on the fact that you are a human like all others in that room and know you have an equal right to sit at the table.

Earn and expect respect. If you aren't respected, call it out, but pick the right moment to do so. Use humor to de-escalate situations, break the ice, or call out disrespect. Kindness also works well. You need to find what works best for you.

Find out what makes you feel confident. Even when you are not, practice ways to exude confidence. Being prepared makes me confident. Being a positive and optimistic person also works well for me. I can always find a positive spin on the worst situation. It helps me not only enjoy my work in sport law, but also to find value in everything I do. If you love what you do, even on your toughest days, there are lessons and positive experiences to be had.

Go into negotiations prepared. It is true that the best prepared person wins. Preparation gives me confidence. Preparation will make you more comfortable speaking and put you in a position to command respect. Being calm is another strategy I use. The more heated negotiations get, the calmer I am. A calm demeanor de-escalates a situation and shuts down your opponent. It's like throwing a curveball when they are expecting a fastball.

When you get to the upper rungs of the sport law ladder, help other women climb up. Don't climb up only to push the ladder over. Make the climb easier for the next woman. They will remember you helped and when you most need it, you will be paid back. Plus, it's more fun to celebrate the collective victories of women in the sport law field, than doing so alone.

\section{There Is More Than One Path}

\section{Anita Moorman ${ }^{14}$}

I often joke that I am a recovering attorney since I no longer practice, but my first career as a practicing attorney was critical to my successful transition into

14 Anita Moorman is a professor of sport administration at the University of Louisville. 
academia. I was fortunate to have an opportunity for a career change to a sport law educator after almost 10 years in private civil law practice with minimal sport industry experience. Now many lawyers and law students are able to specialize in sport law and gain practical legal and business experience simultaneously with a sport organization or league. If you can do that, that is great, but having solid legal experience, particularly litigation experience, will help you develop the analytical and writing skills that will translate well in academia.

Sport business experience and legal experience are equally important and valuable. There is no one perfect pathway to a sport law career. I complemented my legal experience with a master's degree in sport management, extensive volunteering and working sporting events, reading sport business journals, and networking with sport industry practitioners.

If you want to be a sport law educator you also need to be a sport law scholar. I highly recommend finding a balance in your scholarship with a blend of contributions that clearly establish your area of legal expertise and also enable you to work collaboratively with other scholars or practitioners where the law may intersect with policy or business. You want collaborators that make you better and collaborations that make the field or society better. Collaborative work is as challenging as it is rewarding; and it takes time and practice to discover what types of collaborations fit your writing style, working style, and area of expertise.

Lastly, if you read an article, attend a presentation, listen to a podcast, or even read a thread on Twitter that impresses you, let that person know you enjoyed their work and share their work with others. If you are in a position to invite contributions to an article or text, create a panel for an academic conference, or recommend an expert to the media for commentary—be purposeful to identify female sport lawyers and sport law scholars for these opportunities. When you have a chance to lift up the voices, ideas, and scholarly writings of your female colleagues, take it. They will no doubt appreciate it, and with any luck you may have connected with your next or first great collaboration.

\section{Look at the Whole Tree}

\section{Carla Varriale-Barker ${ }^{15}$}

If you are considering practicing sports law, I have two suggestions. The first is obvious and the second is subtle, but important, to your development as a lawyer and, especially, as a sports lawyer.

\footnotetext{
15 Carla Varriale-Barker is a shareholder and Chair, Sports, Recreation \& Entertainment Practice Group, Segal, McCambridge, Singer \& Mahoney.
} 
First: Develop your network. Start now. Your connections start in law school (or earlier). Meet like-minded people who are already practicing, learn from informational interviews, attend sports law conferences, and grab coffee with a web of people who are doing the type of work in which you are interested, or touch on and can nurture your interests. Speak to people (not just lawyers!) already working in the areas of marketing, sponsorship, operations, corporate law, tort law, intellectual property; that's one of the unique things about sports law, it's a tree with many branches. Look at the whole tree, not just one limb, and appreciate how they are interconnected parts of the same tree.

Second: On a related note, be a student of the world, not just a "sports fan." Being a sports fan is irrelevant to appreciating the business of sports or being a good sports lawyer. Read voraciously and keep up on current events that affect sports. This past year was an explosion of developments about name, image, and likeness, and antitrust, for example. These developments did not occur in a vacuum. Ten years ago, I might not have prepared for the impact that sexual abuse, sexual harassment, and LGTBQ rights issues would have on my practice had I not been studying cases and news from across the nation that signaled long-overdue changes were coming. Being a regular and dedicated reader has helped me to understand the developing issues and to be a better advisor to my clients. Don't underestimate the need and the value to consume as much information as possible from cases, legal journals, professional associations, and social media. Twitter is my favorite micro-news site and I like LinkedIn to keep up with colleagues and learn about trends in my practice. They are short bursts of information and easy to digest, so I find them very useful.

I want to sincerely thank the women who contributed their advice (and in doing so, are practicing what they preach!) and I want to thank the authors of the five articles featured here for placing their work in this volume. I also want to thank Thomas Baker and Natasha Brison for inviting me to serve as the guest editor for this special issue. They, and the Sport and Recreation Law Association, represent the best of the sports law community, and I am honored to be part of it. Finally, I hope the ideas and analysis you read in this volume inspire you to work for a more just and inclusive future for sports law.

- Dionne Koller 